\title{
Acute hypokinetic-rigid syndrome following SARS-CoV-2 infection
}

Antonio Méndez-Guerrero, MD, María Isabel Laespada-García, MD, Adolfo Gómez-Grande, MD, Mariano Ruiz-Ortiz, MD, Víctor Antonio Blanco-Palmero, MD, Francisco Javier Azcarate-Diaz, MD, Pablo Rábano-Suárez, MD, Eva Álvarez-Torres, MD, Carlos Pablo de Fuenmayor-Fernández de la Hoz, MD, Diana Vega Pérez, MD, Raquel Rodríguez-Montalbán, MD, Alfredo Pérez-Rivilla, MD, Javier Sayas Catalán, MD, Ana Ramos-González, MD, PhD, and Jesús González de la Aleja, MD, PhD

Neurology ${ }^{\circledR}$ 2020;95:e2109-e2118. doi:10.1212/WNL.0000000000010282

\section{Abstract}

\section{Objective}

To report a case of a patient infected with severe acute respiratory syndrome coronavirus 2 (SARS-CoV-2) who acutely developed a hypokinetic-rigid syndrome.

\section{Methods}

Patient data were obtained from medical records from the Hospital Universitario 12 de Octubre in Madrid, Spain. [ $\left.{ }^{123} \mathrm{I}\right]$-ioflupane dopamine transporter (DaT) SPECT images were acquired 4 hours after a single dose of $185 \mathrm{MBq}$ of ${ }^{123}$ I-FP-CIT. Quantitative analysis was performed with DaTQUANT software providing the specific binding ratio and $z$ score values of the striatum.

\section{Results}

We report a previously healthy 58-year-old man who developed hyposmia, generalized myoclonus, fluctuating and transient changes in level of consciousness, opsoclonus, and an asymmetric hypokinetic-rigid syndrome with ocular abnormalities after a severe SARS-CoV-2 infection. DaT-SPECT confirmed a bilateral decrease in presynaptic dopamine uptake asymmetrically involving both putamina. Significant improvement in the parkinsonian symptoms was observed without any specific treatment.

\section{Conclusion}

This case study provides clinical and functional neuroimaging evidence to support that SARS-CoV-2 can gain access to the CNS, affecting midbrain structures and leading to neurologic signs and symptoms.

\section{Correspondence}

Dr. Méndez-Guerrero mendezguerrero.antonio@ gmail.com

MORE ONLINE

O Video

\section{COVID-19 Resources}

For the latest articles, invited commentaries, and blogs from physicians around the world

NPub.org/COVID19 


\section{Glossary}

CoV $=\beta$-coronavirus; COVID-19 $=$ coronavirus disease 2019; DaT $=$ dopamine transporter; SARS-CoV-2 $=$ severe acute respiratory syndrome coronavirus 2 .

At the end of 2019, a cluster of cases of pneumonia were reported in Wuhan, China. ${ }^{1,2}$ A novel $\beta$-coronavirus (CoV), subsequently called severe acute respiratory syndrome coronavirus 2 (SARS-CoV-2), was identified as the causative agent of the disease, called coronavirus disease 2019 (COVID-19). ${ }^{1}$

Several studies have provided evidence for the neuroinvasive potential of almost all $\beta-\mathrm{CoV},{ }^{3}$ including SARS-CoV, ${ }^{4}$ with which SARS-CoV-2 shares high structural similarity. ${ }^{5} \mathrm{Neu}-$ rologic features in COVID-19 may be relatively common. ${ }^{6}$ Given that detailed neurologic examinations are difficult to perform in an epidemic, some neurologic signs and symptoms may have been previously overlooked. ${ }^{6}$

We report here a patient who developed hyposmia, transient generalized myoclonus and tremor, fluctuating and transient changes in his level of consciousness, intermittent opsoclonus, and finally an asymmetric hypokinetic-rigid syndrome with ocular abnormalities after a severe SARS-CoV-2 infection. In some aspects, this syndrome might resemble von Economo encephalitis lethargica, ${ }^{7}$ a disease for which a viral etiology has long been presumed. ${ }^{8}$

\section{Methods}

Patient data were obtained from the medical records of Hospital Universitario 12 de Octubre in Madrid, Spain. The study was approved by the local ethics committee/institutional review board. The patient provided written informed consent.

Dopamine transporter (DaT)-SPECT image analysis was performed with DaTQUANT software (GE Healthcare, Chicago, IL), providing the specific binding ratio and $z$ score values of the striatum.

\section{Standard protocol approval, registration, and patient consent}

Written informed consent was obtained from the patient participating in the study (consent for research).

\section{Data availability}

The data supporting the findings of this study are available within the article.

\section{Results}

A 58-year-old right-handed man presented to the emergency department with a 7-day history of dry cough, fever, nausea, and shortness of breath. His medical history was remarkable for hypertension and dyslipidemia, which were controlled with enalapril and simvastatin. On admission, he had a fever $\left(38.7^{\circ} \mathrm{C}\right)$ and mild tachypnea. His level of oxygen saturation was $89 \%$ while breathing ambient air. Laboratory test results are shown in table 1 . Chest radiography revealed bilateral diffuse patchy infiltrates. A nasopharyngeal swab was positive for SARS-CoV-2 in a real-time reverse-transcription PCR assay. He was started on empirical treatment as shown in figure 1.

By day 10 after the onset of symptoms, dyspnea worsened. The patient was transferred to the intensive care unit, and mechanical ventilation was initiated. He required a tracheostomy for prolonged ventilation.

After 23 days of mechanical ventilation with no major respiratory issues, the patient was finally weaned from the ventilator. Bilateral and synchronous myoclonic jerks were observed, involving predominantly the distal upper limbs. Myoclonus was present at rest and was aggravated by both postural changes and movements but not by tactile or auditory stimuli. Superimposed mild postural tremor was also noted. The complete blood test showed no metabolic abnormalities. An EEG demonstrated no ictal or interictal epileptiform discharges. Myoclonus spontaneously resolved without specific treatment.

Two days later, on day 36 , he suffered a transient episode of decreased consciousness. This episode was not acute. It lasted several hours and was not accompanied by neurologic deficits or abnormal movements. Respiratory and cardiac monitoring showed no relevant events. Laboratory tests, cranial CT scan, and $\mathrm{CT}$ angiogram showed no abnormalities. Because the patient was stable with acceptable oxygenation levels, there was no need for reinstituting mechanical ventilation. A new EEG was performed, showing diffuse mild and reactive slowing without any asymmetries or epileptiform discharges. A few hours later, the patient experienced another episode of decreased consciousness; he became reactive only to painful stimuli and presented roving eye movements. Bilateral myoclonus in both upper extremities was elicited when the patient was alerted. Brief conjugated, multidirectional, and chaotic saccadic ocular movements compatible with opsoclonus were also observed. Brain MRI results were normal. A systemic examination was performed during the episodes, and the results were unremarkable. He recovered gradually during the subsequent hours.

Once the patient recovered, a detailed neurologic examination was performed. He was aware, and no attention, language, or memory deficits were noted. Nonstandardized olfactory 
Table 1 Main laboratory values during the course of illness ${ }^{a}$

\begin{tabular}{|c|c|c|c|c|c|c|c|c|c|}
\hline \multirow[b]{2}{*}{ /ariable } & \multirow[b]{2}{*}{ Reference range } & \multicolumn{8}{|c|}{ Day of illness } \\
\hline & & 7 & 10 & 18 & 28 & 33 & 36 & 39 & 49 \\
\hline Red cell count (per $1 \mu \mathrm{L}$ ), $n$ & $4,200,000-5,600,000$ & $5,430,000$ & $5,580,000$ & $4,840,000$ & $3,520,000$ & $3,990,000$ & $4,4160,000$ & $4,120,000$ & $4,760,000$ \\
\hline White cell count (per $1 \mu \mathrm{L}$ ), $\mathrm{n}$ & $4,000-11,300$ & 10,300 & 8,000 & 13,400 & 8,800 & 10,400 & 5,900 & 7,100 & 6,200 \\
\hline Absolute neutrophil count (per $1 \mu \mathrm{L}$ ), $n$ & $1,800-7,400$ & 7,700 & 6,800 & 11,700 & 6,400 & 8,000 & 4,700 & 5,300 & 4,500 \\
\hline Absolute lymphocyte count (per $1 \mu \mathrm{L}$ ), n & $1,200-4,000$ & 1,500 & 900 & 700 & 1,400 & 1,200 & 1,000 & 1,000 & 1,100 \\
\hline Hemoglobin, g/dL & $13.0-16.80$ & 16.3 & 16.5 & 14.2 & 10.7 & 12.0 & 12.9 & 12.6 & 13.8 \\
\hline Platelets count (per $1 \mu \mathrm{L}$ ), $\mathrm{n}$ & $140,000-450,000$ & 183,0000 & 199,000 & 240,000 & 219,000 & 185,000 & 180,000 & 217,000 & 226,000 \\
\hline Sodium, mmol/L & $136-145$ & 137 & 139 & 151 & 143 & 137 & 140 & 141 & 142 \\
\hline Potassium, mmol/L & $3.5-5.10$ & 3.79 & 3.87 & 3.29 & 3.85 & 3.71 & 3.34 & 3.52 & 3.64 \\
\hline Calcium, mg/dL & $8.6-10.2$ & - & 8.5 & 8.2 & 9.0 & 8.8 & 8.1 & 8.4 & 8.9 \\
\hline Glucose, mg/dL & $70-110$ & 115 & 122 & 316 & 128 & 120 & 116 & 101 & 107 \\
\hline Creatinine, mg/dL & $0.7-1.2$ & 0.75 & 0.66 & 0.64 & 0.46 & 0.39 & 0.52 & 0.54 & 0.50 \\
\hline Magnesium, mg/dL & $1.6-2.6$ & 1.8 & - & 2.1 & - & - & 2.18 & - & - \\
\hline Blood urea nitrogen, mg/dL & $9-23$ & - & - & - & - & 20.09 & 21.02 & - & - \\
\hline Total protein, g/dL & $6.4-8.3$ & 7.4 & 7.1 & 5.7 & 4.7 & 5.9 & 6.4 & 6.1 & 6.2 \\
\hline Albumin, g/dL & $3.5-5.0$ & 4.1 & 3.7 & 3.4 & 2.7 & 3.5 & 2.8 & 4.1 & 4.0 \\
\hline Alanine aminotransferase, $U / L$ & $5-45$ & 27 & 84 & 48 & 49 & 84 & 25 & 60 & 48 \\
\hline Aspartate aminotransferase, U/L & $5-33$ & 37 & 99 & 21 & 33 & 50 & 40 & 27 & 19 \\
\hline |-Glutamyl transferase, U/L & $8-61$ & 187 & 322 & 320 & 549 & 631 & 53 & 185 & 154 \\
\hline Alkaline phosphatase, U/L & $40-130$ & 106 & 182 & 82 & 101 & 125 & 54 & 82 & 73 \\
\hline Total bilirubin, mg/dL & $0.2-1.0$ & 0.6 & 1.3 & 2.1 & 1.1 & 0.8 & 0.4 & 0.9 & 0.9 \\
\hline actate dehydrogenase, U/L & $135-225$ & 339 & 539 & 353 & 289 & 360 & 461 & 254 & 233 \\
\hline Creatine kinase, U/L & $34-171$ & - & 167 & 56 & 542 & 298 & 28 & - & - \\
\hline Ammonium, $\mu \mathrm{mol} / \mathrm{L}$ & $10-55$ & - & - & - & - & 27 & 28 & - & - \\
\hline Eerritin, ng/mL & $30-400$ & 1,520 & - & - & 1,483 & - & - & - & - \\
\hline -reactive protein, $\mathrm{mg} / \mathrm{dL}$ & $0.10-0.50$ & 5.95 & 10.46 & 0.04 & 0.05 & 0.07 & 0.06 & 0.04 & 0.05 \\
\hline
\end{tabular}


testing showed moderate hyposmia. He had a slight up-gaze restriction. Vertical saccades were produced by moving his eyes in a lateral arc ("round the houses" sign). Smooth pursuit was impaired. Spontaneous intermittent opsoclonus was observed in the primary gaze position. Examination of the remaining cranial nerves was normal. He had a mild proximal tetraparesis (4+ of 5 on the modified Medical Research Council scale). Muscle stretch reflexes were brisk. Normal flexor plantar reflexes were observed. Sensory examination showed no abnormalities. The most remarkable finding was a right side-dominant hypokinetic-rigid syndrome, with mixed postural and resting tremor. Loss of spontaneous movement and moderate cogwheel rigidity enhanced with the Froment maneuver were noticed. Frank hypomimia with diminished blinking and the glabellar tap sign were also elicited (video 1).

At this stage, no drugs known to cause acute parkinsonism were reported or administered (figure 1). The patient had no family history of tremor or parkinsonism. Hyposmia, constipation, REM sleep behavior disorder, and other premorbid parkinsonian symptoms were also absent before infection. An extensive laboratory workup, including CSF analysis (table 2) and repeated contrast-enhanced MRI (figures 2-3), revealed no abnormalities. An [ $\left.{ }^{123} \mathrm{I}\right]$-ioflupane DaT-SPECT showed a bilateral decrease in presynaptic dopamine uptake asymmetrically involving both putamina (figure 4) and was worse on the left side. A SPECT ${ }^{123}$ I-metaiodobenzylguanidine myocardial scintigraphy scan ruled out cardiac autonomic denervation. An electrodiagnostic study was performed 42 days after the onset of symptoms and showed findings consistent with a mild critical illness polyneuoromyopathy. It also revealed a resting tremor of the upper extremities that had a frequency of $7 \mathrm{~Hz}$ (figure 5).

On day 40 , the apomorphine test $(3 \mathrm{mg})$ induced nausea, vomiting, and severe drowsiness. The test was repeated 5 days later using $2 \mathrm{mg}$ of the drug, but no clinical responses were observed. Significant improvement in tremor, rigidity, and bradykinesia was observed without any specific treatment (video 1). At the time of the writing of this report, general recovery and parkinsonism improvement allowed the patient to take a few steps without support.

\section{Discussion}

We report a case of asymmetric hypokinetic-rigid syndrome with mild resting and postural tremor, vertical oculomotor abnormalities, and opsoclonus associated with hyposmia. This condition developed after a severe SARS-CoV-2 infection and a period of transient impaired consciousness and generalized myoclonus. This combination of signs and symptoms suggested the involvement of basal brain structures. The DaTSPECT results demonstrated an asymmetric loss of integrity in the terminal fields of the nigrostriatal neurons. After a comprehensive workup, no etiology other than COVID-19 was found. A striking spontaneous improvement was documented without any specific therapy. 
Figure 1 Clinical course and temporal pattern of the key events

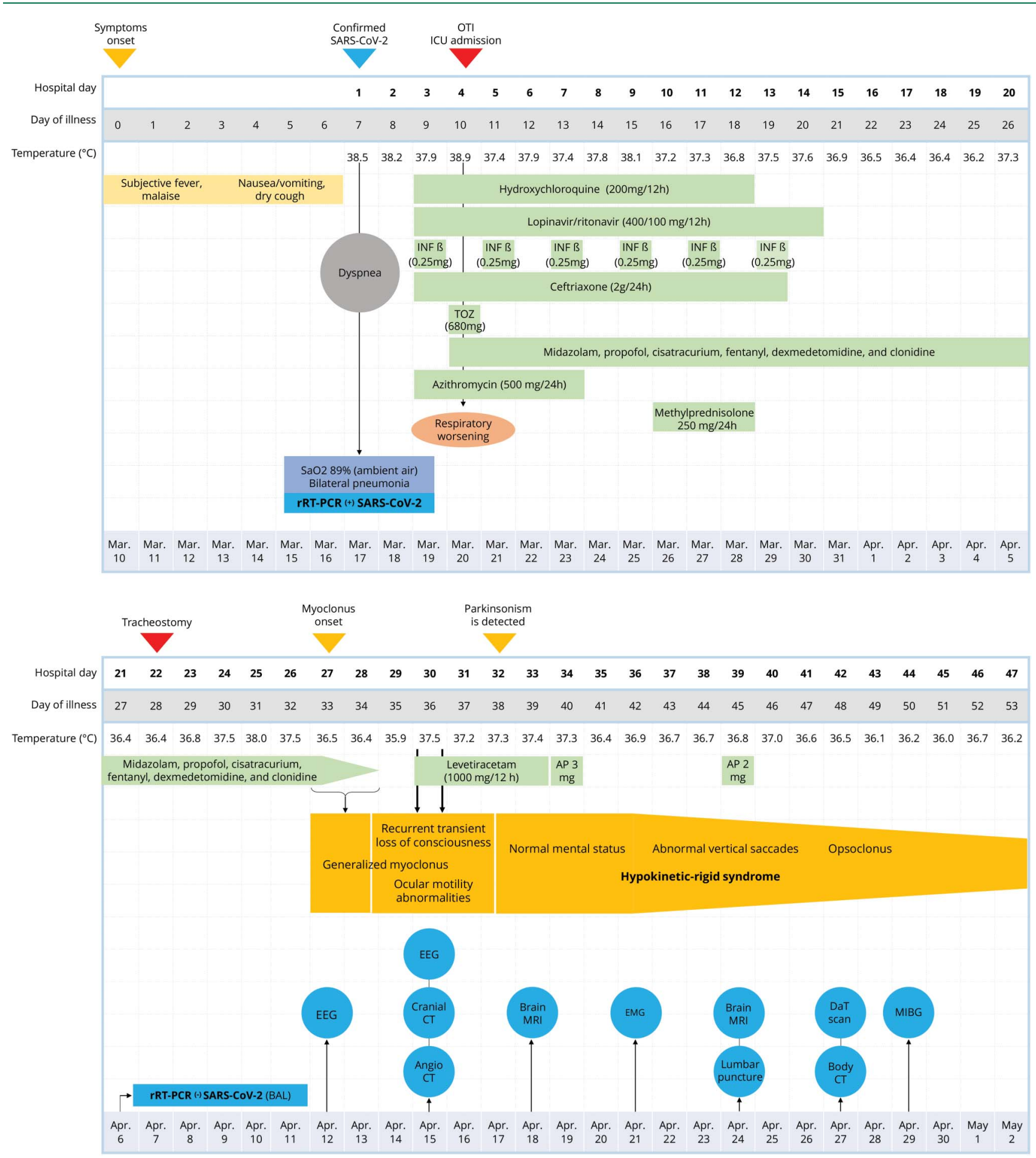

Main clinical events, diagnostic tests performed, and treatments administered. AP = apomorphine; BAL = bronchoalveolar lavage; DaT-SPECT = dopamine transporter SPECT; ICU = intensive care unit; IFN = 1 ß interferon beta-1 b; MIBG iodine $123={ }^{123}$ I-metaiodobenzylguanidine; OTI = orotracheal intubation; rRTPCR = real-time reverse transcription PCR; Sao2 = oxygen saturation; SARS-CoV-2 = severe acute respiratory syndrome coronavirus 2 ; TOZ = tocilizumab.

More than a century ago, Constantin von Economo ${ }^{7}$ published the first cases of encephalitis lethargica. As in the case we describe here, during the acute phase, patients typically experienced excessive sleepiness, ocular motility disorders, and movement disorders (such as myoclonus or rigidity), sometimes with day-to-day changes in symptomatology. ${ }^{8}$ The chronic phase, with postencephalitic parkinsonism, was observed years later. ${ }^{8}$ Since then, scientists have attempted to link some viral infections to movement disorders such as Parkinson disease. ${ }^{9-11}$ Postencephalitic parkinsonism has been reported after infection with certain viruses that can involve the substantia nigra. ${ }^{10}$ Although parkinsonism has not 
Table 2 Specific tests for acute-onset parkinsonism study

\begin{tabular}{ll}
\hline Thyroid function (TSH, T4) & Normal \\
\hline Parathyroid hormone & Normal \\
\hline Vitamin $\mathbf{B}_{12}$ & Normal \\
\hline Folic acid & Normal \\
\hline Serologies (HIV, HBV, HVC, syphilis, Mycoplasma pneumoniae) & Negative \\
\hline Serum copper & Normal \\
\hline Ceruloplasmin & Normal \\
\hline
\end{tabular}

Autoimmune disorders screening

\begin{tabular}{|c|c|}
\hline Non-organ-specific autoimmune disorders ${ }^{a}$ & Negative \\
\hline Onconeuronal and antineuronal surface antibodies ${ }^{b}$ & Negative \\
\hline Other (anti-GAD65 and anti-thyroid antibodies ${ }^{c}$ ) & Negative \\
\hline \multicolumn{2}{|l|}{ CSF analysis } \\
\hline Basic biochemistry and white cell count & $\begin{array}{l}\text { Glucose } 61 \mathrm{mg} / \mathrm{dL}(40-70) \text { (blood glucose } 92 \mathrm{mg} / \mathrm{dL}) ; \text { protein } 0.82 \mathrm{~g} / \mathrm{L}(0.15-0.45) \text {; } \\
\text { white cell count } 8 \text { cells } / \mu \mathrm{L}(0-10)\end{array}$ \\
\hline Microbiological studies ${ }^{d}$ & Negative \\
\hline CSF IgG index & 0.47 (no intrathecal IgG synthesis) \\
\hline Oligoclonal bands & Negative \\
\hline Onconeuronal and antineuronal surface antibodies & Negative \\
\hline Contrast enhanced CT scan of the chest, abdominal, and pelvis & $\begin{array}{l}\text { Chest CT scan showing bilateral peripheral ground-glass opacifications involving } \\
\text { lower lobes, with an area of consolidation in left lung Abdominal and pelvic organs } \\
\text { were normal }\end{array}$ \\
\hline
\end{tabular}

Abbreviations: HBV = hepatitis B virus; HCV = hepatitis C virus; IgG = immunoglobulin G; T4 = thyroxine; TSH = thyroid-stimulating hormone.

a Antibodies: antinuclear, anti-DNA, anti-SSA/Ro, anti-SSA/Ro52, anti-SSA/Ro60, anti-SSB/La, anti-RNP68, anti-centromere protein B, anti-TOPO-1/SCL-70, anti-JO-1/HRS, anti-ribosomal P, anti-Sm, anti-SM-RNP, anti-chromatin, anti-myeloperoxidase, and anti-proteinase3.

b Encephalitis profile: anti-NMDAR, anti-CASPR2, anti-AMPAR1/R2, anti-LGI-1, anti-DDPX, anti-GABAbR, and IgLON5. Onconeuronal antibodies: anti-GAD65, anti-SOX1, anti.Ma-1, anti.Ma-2, anti-amphiphysin, anti-CV2, anti-Ri, anti-Yo, and anti-Hu.

c Anti-thyroid antibodies: anti-thyroid peroxidase antibodies, antithyroglobulin antibodies, and anti-TSH receptor antibodies.

${ }^{d}$ Microbiological studies: Gram staining and bacterial/fungal cultures; PCR assays for detection of severe acute respiratory syndrome coronavirus 2 , Tropheryma whipplei, Mycoplasma pneumoniae, Enterovirus, and Herpes simplex virus 1 and 2; and Venereal Disease Research Laboratory test for syphilis.

been described in association with coronavirus outbreaks, ${ }^{10}$ anti-CoV antibodies have been identified in the CSF of individuals with Parkinson disease. ${ }^{12}$

SARS-CoV and other coronaviruses have the potential to be neuroinvasive in humans. ${ }^{4,13,14}$ Experimental studies have shown that when inoculated intranasally, coronaviruses ${ }^{15,16}$ and other respiratory viruses such as $\mathrm{H} 1 \mathrm{~N} 1^{17}$ and $\mathrm{H} 1 \mathrm{~N} 5^{11}$ spread transneuronally to first- and second-order structures connected with the olfactory bulb. ${ }^{11}$ Certain neuronal populations are then sequentially infected by neuron-to-neuron propagation, affecting areas of the CNS such as the midbrain. Remarkably, these animal models have shown that the virus induces minimal cellular infiltration around infected neurons ${ }^{11,15,17}$ and is not detected in the CSF, as in our case. ${ }^{17}$

We recently reported 3 other patients with COVID-19 who subsequently developed hyposmia, somnolence, and generalized myoclonus. ${ }^{18}$ We hypothesized that SARS-CoV-2 can sequentially affect certain neuronal populations from the olfactory bulb to the diencephalon, eventually reaching the brainstem. ${ }^{18}$

Because no good alternative explanation exists for the occurrence of an asymmetric hypokinetic-rigid syndrome, and all the signs and symptoms of the patient cannot be attributed to any known neurologic disease, we believe that this case study suggests that the CNS is affected by SARS-CoV-2. In this case, we assume that normal MRI findings with no contrast enhancement and a lack of pleocytosis in the CSF cannot rule out neuron infection. We hypothesized this on the basis of the aforementioned experimental animal studies, which showed no histologic lesions or encephalitis. ${ }^{11,15,17}$ We have no explanation for the high CSF protein levels because neither the blood-brain barrier dysfunction nor oligoclonal bands were detected in the CSF. Additional studies quantifying brain-derived proteins in the CSF (such as neurofilaments, $\alpha$-synuclein, or tau protein), markers for neuronal damage (i.e., neuron-specific enolase), and markers for microglia activity (i.e., neopterin) are needed. 
Figure 2 Brain MRI (basal ganglia level)
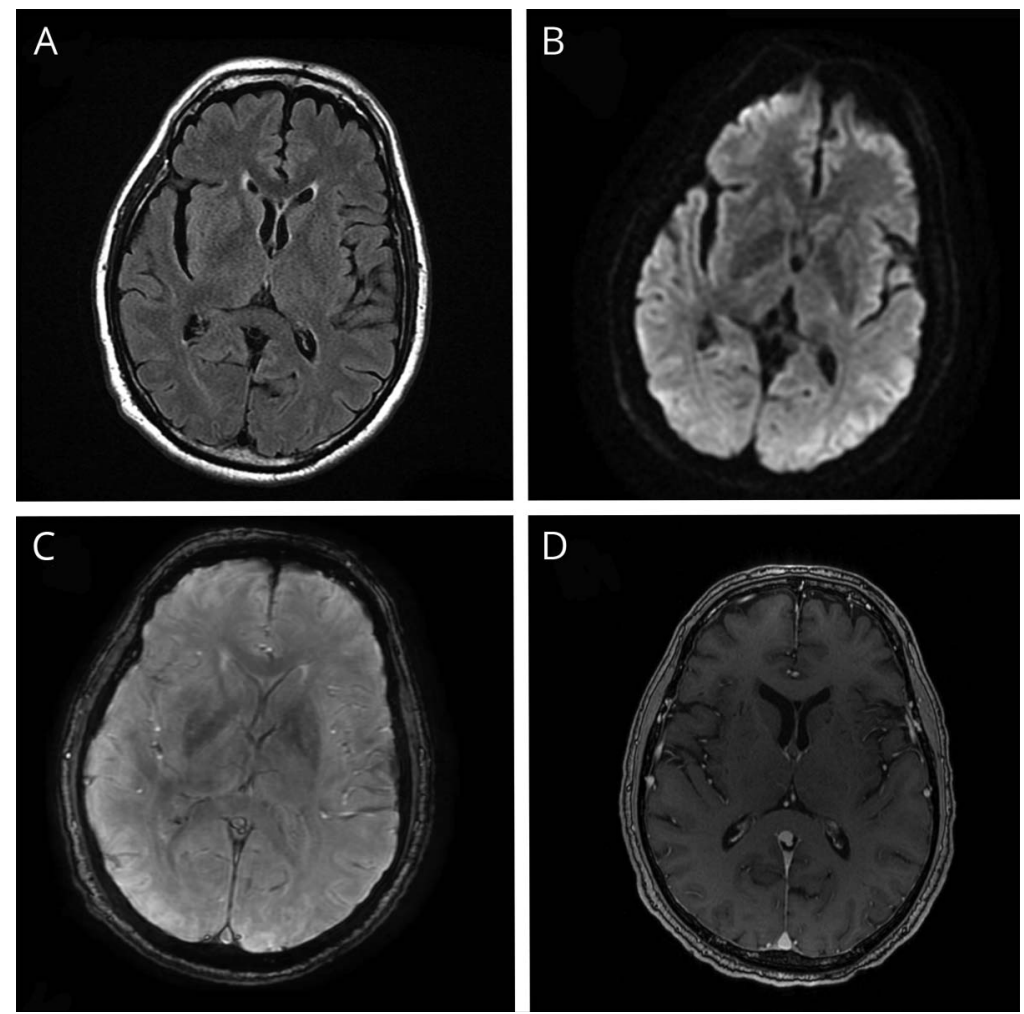

(A) Axial fluid-attenuated inversion recovery image shows no abnormal signal within brain parenchyma. (B) Axial diffusion-weighted imaging sequence shows no evidence of restricted diffusion. (C) Axial susceptibility-weighted imaging shows no microbleeds and no signs of brain iron deposition. (D) Axial gadolinium-enhanced T1-weighted image does not show abnormal enhancement.

Figure 3 Brain MRI (midbrain level)
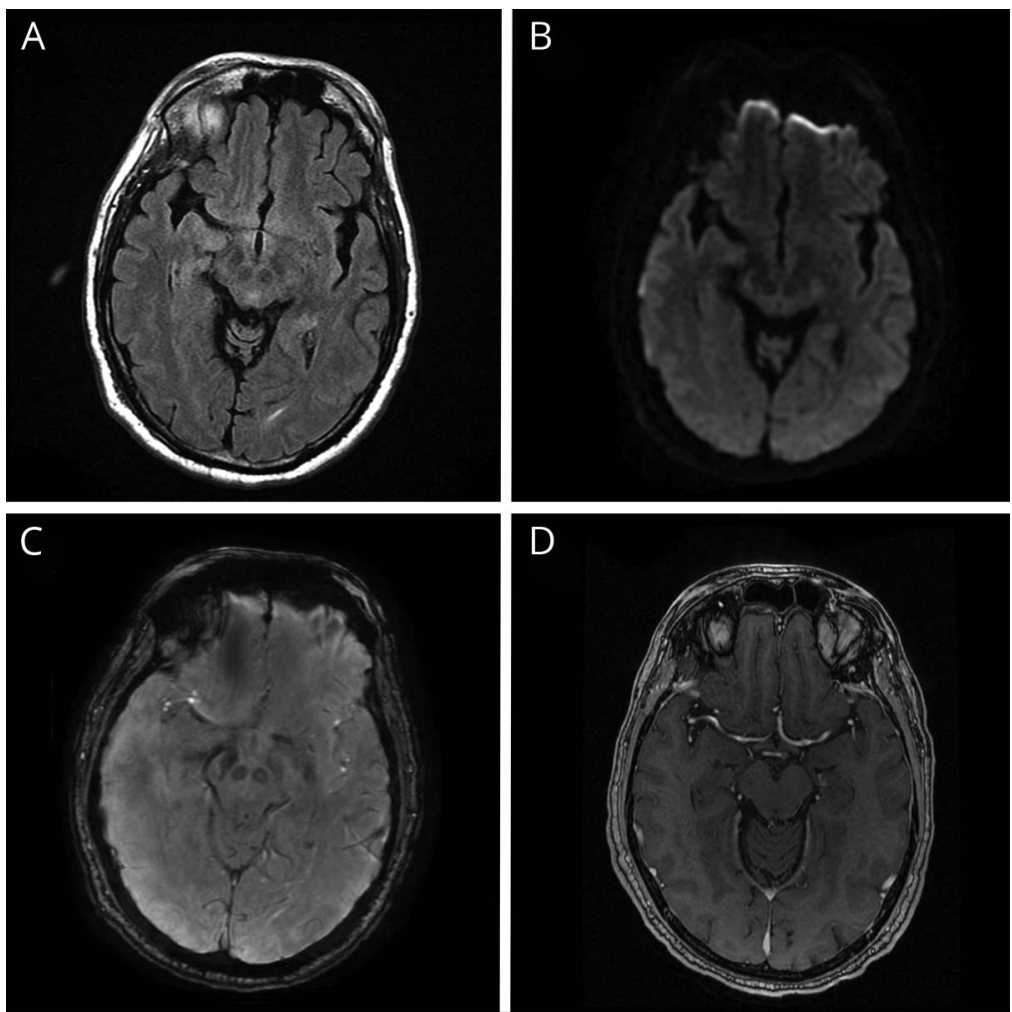

(A) Axial fluid-attenuated inversion recovery image shows no abnormal signal within brain parenchyma. (B) Axial diffusion-weighted imaging sequence shows no evidence of restricted diffusion. (C) Axial susceptibility-weighted imaging shows no microbleeds and no signs of brain iron deposition. (D) Axial gadolinium-enhanced T1-weighted image does not show abnormal enhancement. 


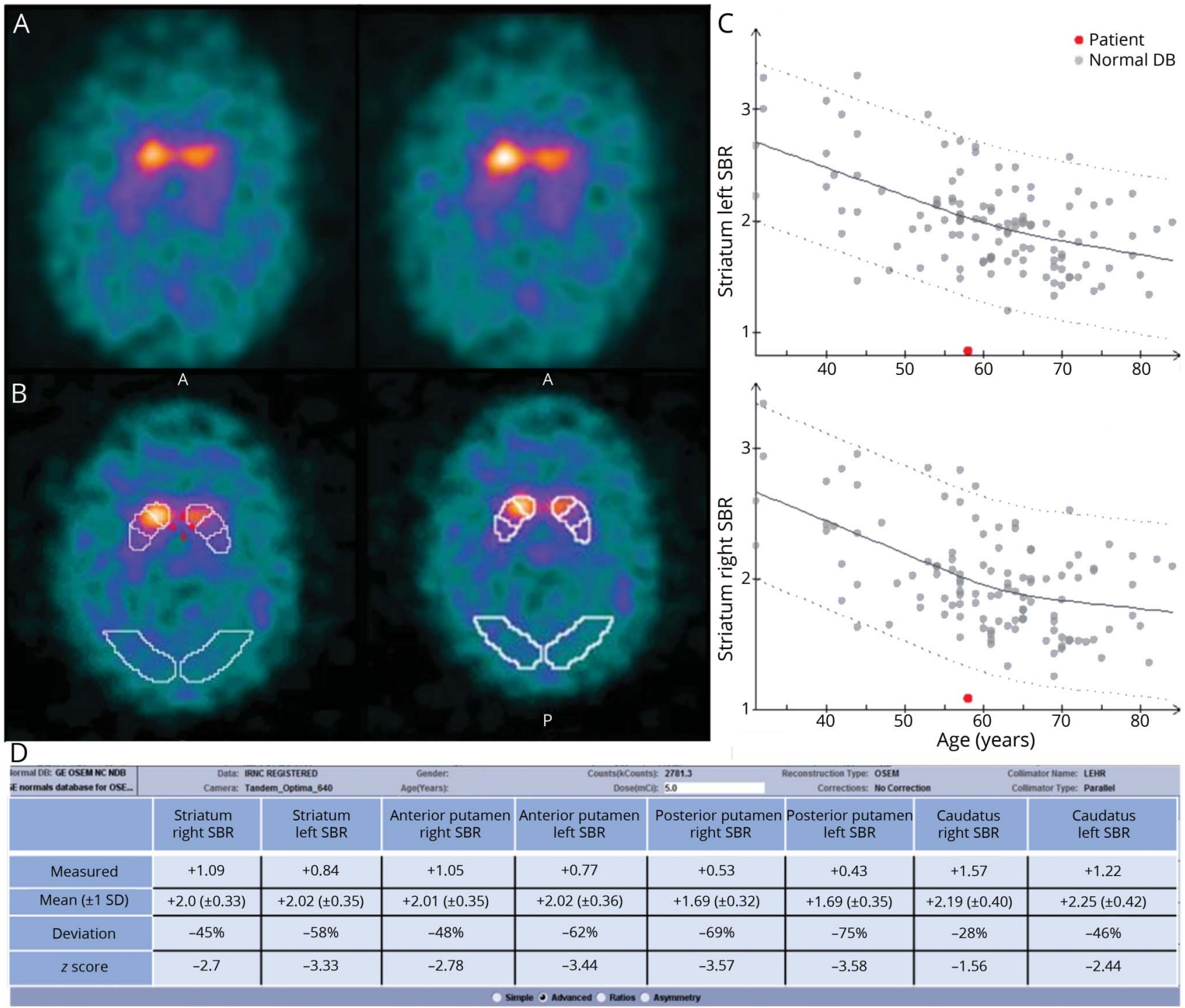

(A) Dopamine transporter (DaT)-SPECT shows a bilaterally reduced nigrostriatal absorption, affecting both putamina, yet asymmetrically, with greater deterioration of the left one. (B) DaTQUANT processing shows a separately delineated voxel of interest (VOIs) to fit the striatum. Reference VOls are established in the bilateral occipital lobes. (C) Gray dots represent the average value from the normal database (DB) cases; dashed lines represent the $95 \%$ confidence interval (2 SDs from the mean); and a red dot represents our case in the both right and left striatal regions of the brain. (D)Striatal binding ratio (SBR) results and age-corrected $z$ score for the left and right striatum are shown in the table. The SBR value is an accurate kinetic parameter that serves as a quantitative evaluation index of specific DAT binding.

The patient experienced a striking but incomplete symptomatic improvement after 14 days without any specific treatment. Some animal models have proposed cellular dysfunction of nigrostriatal neurons resulting from a viral infection. ${ }^{11}$ Whether this mechanism, ${ }^{11}$ a cytolytic effect on neurons, ${ }^{15,17}$ or both processes are involved in this clinical case is a question that cannot be answered at the present time. However, clinical evolution and repeated DaT-SPECT tests will, we hope, shed some light on this issue.

Parainfectious or immune mechanisms affecting the neural function of different midbrain structures might also be considered after COVID-19, and on the basis of the current knowledge, this theory cannot be discarded.

The current report raises concern about the possible shortterm effects of SARS-CoV-2 on the nervous system. Several studies have shown that viruses can activate the innate CNS immune system, causing long-lasting responses in the brain that may persist for years and contribute to protein aggregation disorders and neurodegeneration. ${ }^{11,19}$ Accordingly, long-term effects may be detected in the future. 


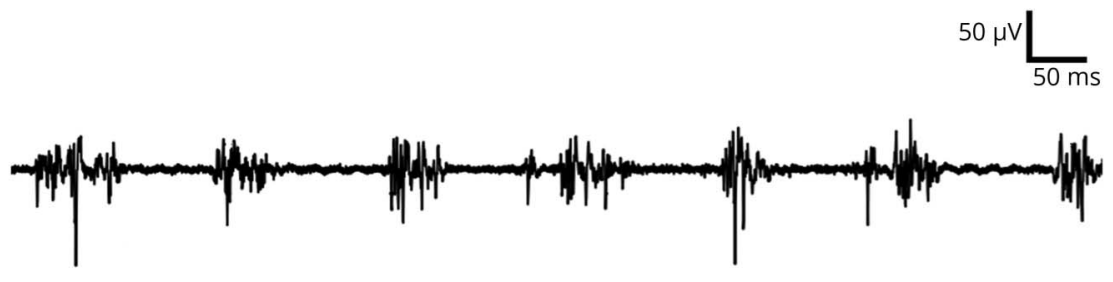

1 second

Needle EMG of right biceps brachii at rest (1-second epoch) shows a tremor with a frequency of $7 \mathrm{~Hz}$.

This case study provides clinical and functional neuroimaging evidence to support that SARS-CoV-2 could gain access to the CNS, affecting midbrain structures and causing neurologic signs and symptoms. Overall, this is a single case report, and more observations are needed to determine whether the CNS is affected by SARS-CoV-2.

\section{Acknowledgment}

The authors acknowledge the patient and his family for understanding the hardships and uncertainties that such an extraordinary clinical picture has implied and for their collaboration in the hope of their case helping other patients. They acknowledge all health workers, patients, and everybody else worldwide who, when facing this once-in-a-lifetime challenge, have taught the value of generosity, determination, and hope in the midst of this pandemic. They also acknowledge Dr. J. Ruiz, whose enthusiasm for and wisdom about neurology have always been a model.

\section{Study funding}

V.A. Blanco-Palmero is supported by the Instituto de Salud Carlos III (ISCIII, Spanish Biomedical Research Institute) through a "Río Hortega" contract (CM 18/0095).

\section{Disclosure}

A. Méndez-Guerrero, M.I. Laespada-García, A. Gómez-Grande, M. Ruiz-Ortiz, V.A. Blanco-Palmero, J.F. Azcarate-Diaz, P. RábanoSuárez, E. Álvarez-Torres, C.P. de Fuenmayor-Fernández de la Hoz, D. Vega Pérez, R. Rodríguez-Montalbán, A. Pérez-Rivilla, J. Sayas Catalán, A. Ramos-González, J. González de la Aleja report no relevant disclosures. Go to Neurology.org/ $\mathrm{N}$ for full disclosures.

\section{Publication history}

Received by Neurology May 13, 2020. Accepted in final form June 22, 2020.

Appendix Authors

\begin{tabular}{lll}
\hline Name & Location & Contribution \\
\hline $\begin{array}{l}\text { Antonio Méndez- } \\
\text { Guerrero, MD }\end{array}$ & $\begin{array}{l}\text { Department of } \\
\text { Neurology, University } \\
\text { Hospital "12 de } \\
\text { Octubre," Madrid, Spain }\end{array}$ & $\begin{array}{l}\text { Conception, organization, } \\
\text { and execution of the } \\
\text { research project; writing } \\
\text { of the first draft; and the } \\
\text { review and critique of the } \\
\text { manuscript }\end{array}$ \\
\end{tabular}

Appendix (continued)

\begin{tabular}{lll}
\hline Name & Location & Contribution \\
\hline $\begin{array}{l}\text { María Isabel } \\
\text { Maespada-García, }\end{array}$ & $\begin{array}{l}\text { Department of } \\
\text { Neurology, University } \\
\text { Hospital "12 de } \\
\text { Octubre," Madrid, Spain }\end{array}$ & $\begin{array}{l}\text { Conception, } \\
\text { organization, and } \\
\text { execution of the } \\
\text { research project; writing } \\
\text { of the first draft; and } \\
\text { review and critique of } \\
\text { the manuscript }\end{array}$ \\
$\begin{array}{ll}\text { Adolfo Gómez- } \\
\text { Grande, MD }\end{array}$ & $\begin{array}{l}\text { Department of Nuclear } \\
\text { Medicine, University }\end{array}$ & $\begin{array}{l}\text { Nuclear medicine } \\
\text { images analysis and the } \\
\text { rospital "12 de } \\
\text { Octubre," Madrid, Spain and critique of } \\
\text { the manuscript }\end{array}$
\end{tabular}

\begin{tabular}{lll}
\hline Mariano Ruiz- & Department of & Conception, \\
Ortiz, MD & Neurology, University & organization, and \\
Hospital "12 de & execution of the \\
Octubre," Madrid, Spain & research project; writing \\
& of the first draft; and \\
& review and critique of \\
& the manuscript
\end{tabular}

\begin{tabular}{|c|c|c|}
\hline $\begin{array}{l}\text { Víctor Antonio } \\
\text { Blanco-Palmero, } \\
\text { MD }\end{array}$ & $\begin{array}{l}\text { Department of } \\
\text { Neurology, University } \\
\text { Hospital "12 de } \\
\text { Octubre," Madrid, Spain }\end{array}$ & $\begin{array}{l}\text { Conception, } \\
\text { organization, and } \\
\text { execution of the } \\
\text { research project; writing } \\
\text { of the first draft; and } \\
\text { review and critique of } \\
\text { the manuscript }\end{array}$ \\
\hline $\begin{array}{l}\text { Francisco Javier } \\
\text { Azcarate-Diaz, } \\
\text { MD }\end{array}$ & $\begin{array}{l}\text { Department of } \\
\text { Neurology, University } \\
\text { Hospital "12 de } \\
\text { Octubre," Madrid, Spain }\end{array}$ & $\begin{array}{l}\text { Conception and } \\
\text { organization of the } \\
\text { research project; video } \\
\text { editing; review and } \\
\text { critique of the } \\
\text { manuscript }\end{array}$ \\
\hline $\begin{array}{l}\text { Pablo Rábano- } \\
\text { Suárez, MD }\end{array}$ & $\begin{array}{l}\text { Department of } \\
\text { Neurology, University } \\
\text { Hospital "12 de } \\
\text { Octubre," Madrid, Spain }\end{array}$ & $\begin{array}{l}\text { Conception, } \\
\text { organization, and } \\
\text { execution of the } \\
\text { research project; writing } \\
\text { of the first draft; and } \\
\text { review and critique of } \\
\text { the manuscript }\end{array}$ \\
\hline $\begin{array}{l}\text { Eva Álvarez- } \\
\text { Torres, MD, PhD }\end{array}$ & $\begin{array}{l}\text { Department of } \\
\text { Anesthesiology, } \\
\text { University Hospital "12 } \\
\text { de Octubre," Madrid, } \\
\text { Spain }\end{array}$ & $\begin{array}{l}\text { Organization of the } \\
\text { research project; review } \\
\text { and critique of the } \\
\text { manuscript }\end{array}$ \\
\hline $\begin{array}{l}\text { Carlos Pablo de } \\
\text { Fuenmayor- } \\
\text { Fernández de la } \\
\text { Hoz, MD }\end{array}$ & $\begin{array}{l}\text { Department of } \\
\text { Neurology, University } \\
\text { Hospital "12 de } \\
\text { Octubre," Madrid, Spain }\end{array}$ & $\begin{array}{l}\text { Conception and } \\
\text { organization of the } \\
\text { research project; } \\
\text { electrophysiologic } \\
\text { study; and review and } \\
\text { critique of the } \\
\text { manuscript }\end{array}$ \\
\hline
\end{tabular}


Appendix (continued)

\begin{tabular}{|c|c|c|}
\hline Name & Location & Contribution \\
\hline $\begin{array}{l}\text { Diana Vega- } \\
\text { Pérez, MD }\end{array}$ & $\begin{array}{l}\text { Department of Nuclear } \\
\text { Medicine, University } \\
\text { Hospital "12 de } \\
\text { Octubre," Madrid, } \\
\text { Spain }\end{array}$ & $\begin{array}{l}\text { Nuclear medicine } \\
\text { images analysis; review } \\
\text { and critique of the } \\
\text { manuscript }\end{array}$ \\
\hline $\begin{array}{l}\text { Raquel } \\
\text { Rodríguez- } \\
\text { Montalbán, MD }\end{array}$ & $\begin{array}{l}\text { Department } \\
\text { Anesthesiology, } \\
\text { University Hospital "12 } \\
\text { de Octubre," Madrid, } \\
\text { Spain }\end{array}$ & $\begin{array}{l}\text { Organization of the } \\
\text { research project; review } \\
\text { and critique of the } \\
\text { manuscript }\end{array}$ \\
\hline $\begin{array}{l}\text { Alfredo Pérez- } \\
\text { Rivilla, MD }\end{array}$ & $\begin{array}{l}\text { Department of } \\
\text { Microbiology, University } \\
\text { Hospital "12 de } \\
\text { Octubre," Madrid, } \\
\text { Spain }\end{array}$ & $\begin{array}{l}\text { Organization of the } \\
\text { research project; review } \\
\text { and critique of the } \\
\text { manuscript }\end{array}$ \\
\hline $\begin{array}{l}\text { Javier Sayas- } \\
\text { Catalán, MD }\end{array}$ & $\begin{array}{l}\text { Department of } \\
\text { Pneumology, University } \\
\text { Hospital "12 de } \\
\text { Octubre," Madrid, } \\
\text { Spain }\end{array}$ & $\begin{array}{l}\text { Organization of the } \\
\text { research project; review } \\
\text { and critique of the } \\
\text { manuscript }\end{array}$ \\
\hline $\begin{array}{l}\text { Ana Ramos- } \\
\text { González, MD, } \\
\text { PhD }\end{array}$ & $\begin{array}{l}\text { Department of } \\
\text { Neuroradiology, } \\
\text { University Hospital "12 } \\
\text { de Octubre," Madrid, } \\
\text { Spain }\end{array}$ & $\begin{array}{l}\text { Organization of the } \\
\text { research project; review } \\
\text { and critique of the } \\
\text { manuscript }\end{array}$ \\
\hline $\begin{array}{l}\text { Jesús González } \\
\text { de la Aleja, MD, } \\
\text { PhD }\end{array}$ & $\begin{array}{l}\text { Department of } \\
\text { Neurology, University } \\
\text { Hospital "12 de } \\
\text { Octubre," Madrid, Spain }\end{array}$ & $\begin{array}{l}\text { Conception, } \\
\text { organization, and } \\
\text { execution of the } \\
\text { research project; } \\
\text { writing of the } \\
\text { manuscript first draft; } \\
\text { and the review and } \\
\text { critique of the } \\
\text { manuscript }\end{array}$ \\
\hline
\end{tabular}

\section{References}

1. World Health Organisation. Novel coronavirus-China. Geneva: World Health Organization; 2020. https://www.who.int/csr/don/12-january-2020-novel-coronavirus-china/en/.

2. Huang C, Wang Y, Li X, et al. Clinical features of patients infected with 2019 novel coronavirus in Wuhan, China. Lancet 2020;395:497-506.

3. Desforges M, Le Coupanec A, Stodola JK, Meessen-Pinard M, Talbot PJ. Human coronaviruses: viral and cellular factors involved in neuroinvasiveness and neuropathogenesis. Virus Res 2014:145-158.

4. Ding Y, He L, Zhang Q et al. Organ distribution of severe acute respiratory syndrome (SARS) associated coronavirus (SARS-CoV) in SARS patients: implications for pathogenesis virus transmission pathways. J Pathol 2004;203:622-630.

5. Lu R, Zhao X, Li J, et al. Genomic characterisation and epidemiology of 2019 novel coronavirus: implications for virus origins and receptor binding. Lancet 2020;395:565-574.

6. Mao L, Jin H, Wang M, et al. Neurologic manifestations of hospitalized patients with coronavirus disease 2019 in Wuhan, China. JAMA Neurol 2020;77:1-9.

7. von Economo C. Encephalitis lethargica. Wiener Klin Wochenschr 1917;30:581-585.

8. Hoffman LA, Vilensky JA. Encephalitis lethargica: 100 years after the epidemic. Brain 2017;140:2246-2251.

9. Hawkes CH, Del Tredici K, Braak H. Parkinson's disease: a dual-hit hypothesis. Neuropathol Appl Neurobiol 2007:599-614.

10. Limphaibool N, Iwanowski P, Holstad MJV, Kobylarek D, Kozubski W. Infectious etiologies of Parkinsonism: pathomechanisms and clinical implications. Front Neurol 2019;10:652

11. Jang H, Boltz D, McClaren J, et al. Inflammatory effects of highly pathogenic H5N1 influenza virus infection in the CNS of mice. J Neurosci 2012;32:1545-1559.

12. Fazzini E, Fleming J, Fahn S. Cerebrospinal fluid antibodies to coronavirus in patients with Parkinson's disease. Mov Disord 1992;7:153-158.

13. Gu J, Gong E, Zhang B, et al. Multiple organ infection and the pathogenesis of SARS J Exp Med 2005;202:415-424.

14. Xu J, Zhong S, Liu J, et al. Detection of severe acute respiratory syndrome coronavirus in the brain: potential role of the chemokine mig in pathogenesis. Clin Infect Dis 2005;41:1089-1096.

15. Netland J, Meyerholz DK, Moore S, Cassell M, Perlman S. Severe acute respiratory syndrome coronavirus infection causes neuronal death in the absence of encephalitis in mice transgenic for human ACE2. J Virol 2008;82:7264-7275.

16. Dubé M, Le Coupanec A, Wong AHM, Rini JM, Desforges M, Talbot PJ. Axonal transport enables neuron-to-neuron propagation of human coronavirus OC43. J Virol 2018;92:e00404-e00418.

17. de Wit E, Siegers JY, Cronin JM, et al. 1918 H1N1 influenza virus replicates and induces proinflammatory cytokine responses in extrarespiratory tissues of ferrets. J Infect Dis 2018;217:1237-1246.

18. Rábano-Suárez P, Bermejo-Guerrero L, Méndez-Guerrero A, et al. Generalized myoclonus in COVID-19. Neurology Epub 2020 May 21.

19. Sadasivan S, Zanin M, O'Brien K, Schultz-Cherry S, Smeyne RJ. Induction of microglia activation after infection with the non-neurotropic A/CA/04/2009 H1N1 influenza virus. PLoS One 2015;10:e0124047. 


\section{Neurology}

\section{Acute hypokinetic-rigid syndrome following SARS-CoV-2 infection}

Antonio Méndez-Guerrero, María Isabel Laespada-García, Adolfo Gómez-Grande, et al. Neurology 2020;95;e2109-e2118 Published Online before print July 8, 2020

DOI 10.1212/WNL.0000000000010282

\section{This information is current as of July 8, 2020}

\section{Updated Information \& Services}

References

Citations

Subspecialty Collections

Permissions \& Licensing

Reprints including high resolution figures, can be found at: http://n.neurology.org/content/95/15/e2109.full

This article cites 15 articles, 3 of which you can access for free at: http://n.neurology.org/content/95/15/e2109.full\#ref-list-1

This article has been cited by 3 HighWire-hosted articles: http://n.neurology.org/content/95/15/e2109.full\#\#otherarticles

This article, along with others on similar topics, appears in the following collection(s):

Myoclonus

http://n.neurology.org/cgi/collection/myoclonus

Parkinson's disease/Parkinsonism

http://n.neurology.org/cgi/collection/parkinsons_disease_parkinsonism

Information about reproducing this article in parts (figures,tables) or in its entirety can be found online at:

http://www.neurology.org/about/about_the_journal\#permissions

Information about ordering reprints can be found online:

http://n.neurology.org/subscribers/advertise

Neurology ${ }^{\circledR}$ is the official journal of the American Academy of Neurology. Published continuously since 1951, it is now a weekly with 48 issues per year. Copyright () 2020 American Academy of Neurology. All rights reserved. Print ISSN: 0028-3878. Online ISSN: 1526-632X.

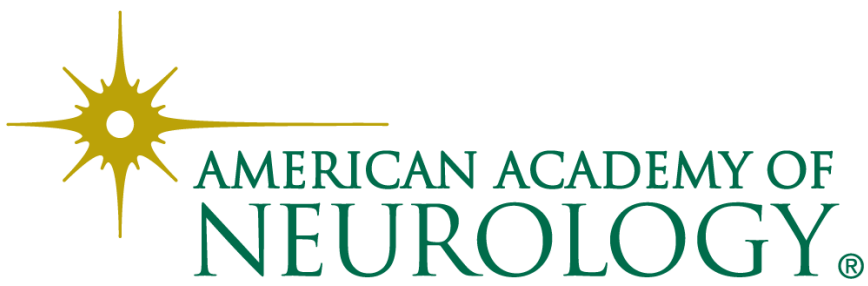

